\title{
Effectiveness of extruded rapeseed associated with an alfalfa protein concentrate in enhancing the bovine milk fatty acid composition
}

\author{
Q. C. Dang Van, ${ }^{* 1}$ L. Bejarano, ${ }^{*}$ E. Mignolet, ${ }^{*}$ D. Coulmier,† E. Froidmont, $¥$ Y. Larondelle, ${ }^{*}$ and M. Focant ${ }^{\star} \S$ \\ *Institut des Sciences de la Vie, Université catholique de Louvain, 2/8 Croix du Sud, B-1348 Louvain-la-Neuve, Belgium \\ †Désialis, BP 124, 51007 Châlons-en-Champagne cedex, France \\ fUnité Nutrition animale et Durabilité, Département Production et Filières, Centre wallon de Recherches agronomiques, 8 rue de Liroux, \\ B-5030 Gembloux, Belgium \\ §Institut supérieur industriel agronomique, Haute Ecole Charlemagne, 3 rue Saint Victor, B-4500 Huy, Belgium
}

\section{ABSTRACT}

Linseed and rapeseed, good sources of 18:3 n-3 and cis9-18:1, respectively, have been shown to improve the bovine milk fatty acid (FA) profile. However, rapeseed, unlike linseed, has little effect on the concentration of 18:3 n-3 in milk fat. Alfalfa protein concentrate (APC), besides being a valuable protein source for milk production, contains lipids rich in 18:3 n-3. Therefore, this experiment aimed at (1) evaluating the transfer efficiency of unsaturated FA (UFA), especially 18:3 n-3, of APC to bovine milk fat, and (2) evaluating whether extruded rapeseed (ER) associated with APC is as effective as extruded linseed (EL) in enhancing the bovine milk fat composition. Six lactating Holstein cows were used in a replicated $2 \times 2$ Latin square design with 2 iso-energy, iso-nitrogen and iso-FA corn silage-based diets (EL and ER-APC) and two 21-d periods. Extruded linseed, as main UFA source, was included in the first diet, whereas $\mathrm{ER}$, as main UFA source, and APC, as supplemental 18:3 n-3, were included in the second diet. Diets were distributed as a restricted total mixed ration. Compared with the EL diet, the ER-APC diet, where ER was associated with APC, increased milk concentration of $18: 3$ n-3 (1.18 vs. $1.31 \%$ of FA) and cis9-18:1 (18.35 vs. $20.01 \%$ of FA). The apparent transfer efficiency of 18:3 n-3 from diet to milk was almost twice as much for the ER-APC diet than for the EL diet (7.4 vs. 3.8\% of intake). Extruded linseed accounted for $84 \%$ of $18: 3$ n-3 provided in the EL diet, whereas ER and APC accounted for 33 and $38 \%$ of 18:3 n-3 provided in the ER-APC diet, respectively. Because both EL and ER underwent extrusion in similar conditions, these results suggest that 18:3 n-3 of EL in the EL diet and ER in the ER-APC diet were subjected to more extensive ruminal biohydrogenation than 18:3 n-3 of APC in the ER-APC diet. This experiment shows that corn silage-

Received January 24, 2011.

Accepted April 11, 2011

${ }^{1}$ Corresponding author: quynh.dangvan@uclouvain.be based diets supplemented with ER as the main UFA source, associated with APC as supplemental 18:3 n-3, are as effective as corn silage-based diets supplemented with EL as the main UFA source, in increasing bovine milk UFA and 18:3 n-3 contents. Furthermore, at similar levels of dietary incorporation, this experiment shows that the ruminal bypass of $18: 3 n-3$ is higher for APC compared with EL.

Key words: alfalfa protein concentrate, milk fatty acid, linseed, rapeseed

\section{INTRODUCTION}

Extensive research has been done to enhance the nutritional quality of bovine milk fat through the diet, the major aim being to increase the unsaturated fatty acid (UFA), n-3 polyunsaturated fatty acid (PUFA), and conjugated linoleic acid (CLA) contents because of their bioactive properties in human health. The most common nutritional means to enhance milk UFA contents, including CLA, is to use oilseeds such as cottonseed, linseed, rapeseed, soybean, or sunflower seed in the dairy cow diet.

Among oilseeds, linseed has the highest content in 18:3 n-3, representing more than 50\% of total fatty acids (FA). Feeding linseed decreases milk concentrations of short- and medium-chain FA (SMCFA) and saturated FA (SFA), and consequently, increases those of long-chain FA and UFA, more specifically 18:3 n-3 and CLA, when compared with a control diet without linseed (Gonthier et al., 2005; Akraim et al., 2007). For these reasons, linseed has become the reference in Northern and Western Europe for improving the bovine milk FA profile, and thus, has been widely used both on commercial farms and for experimental work. In Europe, rapeseed has become more available in recent years because of its increased production, whereas linseed is mainly imported. Rapeseed is a good source of cis (c) $9-18: 1$, representing more than $50 \%$ of total FA. Rapeseed has been shown to improve the milk FA profile by increasing concentrations of UFA and $c 9-18: 1$ 
and decreasing those of SMCFA, when compared with a control diet without rapeseed (Bayourthe et al., 2000; Collomb et al., 2004). However, rapeseed had little (Bayourthe et al., 2000) or no effect (Collomb et al., 2004) on the concentrations of 18:3 n-3 and CLA in milk fat.

Alfalfa is known to be a good source of protein and can be fed to dairy cows either as fresh, dehydrated, silage, hay, or protein concentrate. The alfalfa protein concentrate (APC) is obtained by heat-treatment and drying of the liquid fraction high in protein expressed from the fresh alfalfa plant. Alfalfa protein concentrate is known to be a valuable protein source for milk production because it is more resistant to ruminal degradation compared with conventional protein sources such as soybean meal (Lu et al., 1982, 1988). Interestingly, APC contains approximately 10\% lipids (DM basis; INRA, 2007) rich in 18:3 n-3. Kim et al. (2009) found that a beef steer diet with APC resulted in the highest level of n- 6 and n-3 PUFA in meat relative to other diets and suggested that this may relate to the rumenprotected nature of the lipids in APC.

To our knowledge, no information is available in the literature on the UFA transfer efficiency from rapeseed associated with APC to milk fat in lactating dairy cows. Therefore, the objective of the present experiment was (1) to evaluate the transfer efficiency of UFA, especially 18:3 n-3, of APC to bovine milk fat, and (2) to evaluate whether extruded rapeseed (ER) associated with APC is as effective as extruded linseed (EL) in improving the bovine milk fat composition.

\section{MATERIALS AND METHODS}

\section{Experimental Design, Animals, and Management}

Six lactating Holstein cows were blocked according to their milk yield and assigned to 2 dietary treatments in a replicated $2 \times 2$ Latin square design. Each experimental period lasted $21 \mathrm{~d}$. At the beginning of the experiment, cows averaged $3 \pm 0.8$ lactations, $162 \pm$ 44.4 DIM, $636 \pm 25.3 \mathrm{~kg}$ of BW, and yielded $30.1 \pm$ $4.32 \mathrm{~kg}$ of milk/d (mean $\pm \mathrm{SD}$ ). Cows were housed in individual stalls. The floor of the stalls was bedded with mats and sawdust and cleaned twice daily. Cows were fed individually twice daily at 0830 and $1730 \mathrm{~h}$ and had free access to water and mineral blocks. Milking took place twice daily at 0730 and $1630 \mathrm{~h}$. The experiment was carried out at the Centre wallon de Recherches agronomiques (Gembloux, Belgium) from April 23 to June 3, 2009, and was in accordance with the recommendations on care and use of laboratory animals of the Université catholique de Louvain.

\section{Experimental Diets}

Two diets (EL and ER-APC) were formulated to provide similar forage-to-concentrate ratios (60:40) and similar amounts of energy, nitrogen, and FA. The ingredient composition of the experimental diets is given in Table 1. Diets contained corn silage and grass hay as forages in the same proportions, soybean meal (in the EL diet) or APC (in the ER-APC diet) and urea as sources of nitrogen, sugar beet pulp as a source of energy, EL (in the EL diet) or ER and APC (in the ER-APC diet) as sources of supplemental UFA, a mineral and vitamin mix, ground chalk, and a vitamin E preparation to avoid milk oxidation (Focant et al., 1998). The DM content and chemical composition of the main individual feedstuffs are given in Table 2. Extruded linseed, supplied as Nutex (Dumoulin, Seilles, Belgium) consisted of an extruded mixture of linseed, wheat, sunflower cake, field beans, peas, butylated hydroxytoluene (BHT) and salt $(58.5,15.0,14.0,5.0,5.0$, 2.0 and $0.4 \%$ of total raw materials, respectively). The extrusion of the linseed mixture was performed with a one-screw Wenger extruder (Wenger Manufacturing Inc., Sabetha, KS) at $108^{\circ} \mathrm{C}$ after pre-conditioning with steam at $96^{\circ} \mathrm{C}$ for 3 min to adjust the moisture content of the raw linseed mixture to $22 \%$. The total FA of EL was $23.6 \%$ of DM, with the main FA being 18:3 n-3, c9-18:1 and 18:2 n- $6(52,21$, and $17 \%$ of identified FA, respectively). Extruded rapeseed, supplied as Colmex (Dumoulin), consisted of an extruded mixture of rapeseed, wheat, BHT and salt $(70.0,28.0,1.5$, and $0.5 \%$ of total raw material, respectively). The extrusion of the rapeseed mixture was performed in the same conditions as described above for EL. The total FA of ER was $30.0 \%$ of DM, with the main FA being $c 9-18: 1,18: 2$ n-6, and 18:3 n-3 (55, 22, and $12 \%$ of identified FA, respectively). Alfalfa protein concentrate, supplied as Extraluz (Désialis, Paris, France), was obtained as follows. A liquid fraction (green juice) rich in protein was cold-expressed from fresh alfalfa. It was then treated for the flocculation of all the pigmented and cytoplasmic proteins contained in it by (1) alkalinization to $\mathrm{pH} 8.5$ through injection of $\mathrm{NH}_{3}$, followed by (2) thermal flocculation by raising the temperature of the juice to 85 to $90^{\circ} \mathrm{C}$ (2 min) through the use of a steam injector. The protein-lipid coagulum was then centrifuged to separate the green cream ( $>40 \%$ of DM) from the liquid effluent (serum). The green cream was then pelletized and finally dried by hot air fluidization to obtain APC in the form of green dehydrated pellets. The CP of the APC was $58.2 \%$ of DM. The total FA of the APC was $6.7 \%$ of DM, with the main FA being 18:3 n-3, 16:0 and 18:2 n- 6 $(47,18$, and $17 \%$ of identified FA, respectively). 
Table 1. Ingredient composition (\% DM) of the 2 experimental diets ${ }^{1}$

\begin{tabular}{|c|c|c|}
\hline \multirow[b]{2}{*}{ Ingredient } & \multicolumn{2}{|c|}{ Diet $^{2}$} \\
\hline & EL & ER-APC \\
\hline Corn silage & 50.0 & 50.9 \\
\hline Grass hay & 10.2 & 10.2 \\
\hline Sugar beet pulp & 15.7 & 20.8 \\
\hline Soybean meal & 13.0 & 0.0 \\
\hline Alfalfa protein concentrate ${ }^{3}$ & 0.0 & 9.3 \\
\hline Extruded linseed ${ }^{4}$ & 9.3 & 0.0 \\
\hline Extruded rapeseed $^{5}$ & 0.0 & 6.9 \\
\hline Urea $^{6}$ & 0.5 & 0.9 \\
\hline Mineral and vitamin $\operatorname{mix}^{7}$ & 0.9 & 0.9 \\
\hline Ground chalk ${ }^{8}$ & 0.5 & 0.0 \\
\hline
\end{tabular}

${ }^{1}$ The two experimental diets received a vitamin $\mathrm{E}$ preparation distributed in the form of a powder containing $50 \%$ of $\alpha$-tocopheryl acetate (Dumoulin, Seilles, Belgium) added to the TMR; the amount was calculated to deliver 10,000 IU/d of unprotected vitamin $\mathrm{E}$ to the diet.

${ }^{2} \mathrm{EL}=$ extruded linseed diet; ER-APC diet = extruded rapeseed-alfalfa protein concentrate diet.

${ }^{3}$ Commercial alfalfa protein concentrate (Extraluz; Désialis, Paris, France).

${ }^{4}$ Extruded commercial concentrate (Nutex; Dumoulin) made of linseed, wheat, sunflower cake, field beans, peas, butylated hydroxytoluene (BHT), and salt $(58.5,15.0,14.0,5.0,5.0,2.0$, and $0.4 \%$ of total raw materials, respectively).

${ }^{5}$ Extruded commercial concentrate (Colmex; Dumoulin) made of rapeseed, wheat, BHT, and salt $(70.0,28.0,1.5$, and $0.5 \%$ of total raw material, respectively).

${ }^{6}$ Urea: $98.0 \%$ of DM and $287.5 \%$ of CP on a DM basis (INRA, 2007).

${ }^{7}$ Declared contents: $15 \% \mathrm{Ca}, 5 \% \mathrm{Mg}, 5 \% \mathrm{P}, 1 \% \mathrm{Na}, 7,750 \mathrm{mg}$ of $\mathrm{Zn} /$ $\mathrm{kg}, 3,300 \mathrm{mg}$ of $\mathrm{Mn} / \mathrm{kg}, 1,250 \mathrm{mg}$ of $\mathrm{Cu} / \mathrm{kg}, 100 \mathrm{mg}$ of I/ $\mathrm{kg}, 50 \mathrm{mg}$ of $\mathrm{Co} / \mathrm{kg}, 20 \mathrm{mg}$ of Se $/ \mathrm{kg}, 1,200,000 \mathrm{IU}$ of vitamin $\mathrm{A} / \mathrm{kg}, 200,000 \mathrm{IU}$ of vitamin $\mathrm{D}_{3} / \mathrm{kg}, 15,000 \mathrm{mg}$ of choline $/ \mathrm{kg}, 2,000 \mathrm{mg}$ of vitamin $\mathrm{E} / \mathrm{kg}$, $500 \mathrm{mg}$ of vitamin $\mathrm{B}_{1} / \mathrm{kg}, 255 \mathrm{mg}$ of vitamin $\mathrm{B}_{3} / \mathrm{kg}$, $75 \mathrm{mg}$ of vitamin $\mathrm{B}_{2} / \mathrm{kg}, 15 \mathrm{mg}$ of vitamin $\mathrm{B}_{6} / \mathrm{kg}, 15 \mathrm{mg} / \mathrm{kg}$ of vitamin $\mathrm{K}$ (Celemin; Dumoulin).

${ }^{8}$ Ground chalk: $99.5 \%$ of DM and $99 \%$ of crude ash on a DM basis (Dumoulin).

Diets were formulated to meet energy and protein requirements of cows according to the French Unité Fourragère Lait and Protéines Digestibles dans l'Intestin systems using the INRAtion software (version 3.21;
INRA, Paris, France) for a cow of $650 \mathrm{~kg}$ yielding $30 \mathrm{~kg}$ of milk/d. The amounts of diets were distributed as a restricted TMR to control intakes and were adapted to the individual milk production of cows.

\section{Measurements}

Individual feedstuffs were sampled at the end of each period and analyzed for DM and chemical composition. Individual cow refusals were collected during the last week of each period and analyzed for DM content. Individual cow intakes during the last week of each period were calculated for each ingredient as the amounts offered minus refusals, on a DM basis. Means of individual cow intakes calculated during the last week of each period were included in the statistical analysis. Individual cow milk yield was recorded daily during each milking. Means of individual cow milk yields recorded during the last week of each period were included in the statistical analysis. Milk samples from individual cows were collected on d 19 and 21 of each period at the a.m. and p.m. milkings. The a.m. and p.m. milk samples of each of the $2 \mathrm{~d}$ from individual cows were mixed in a proportional basis for analysis. These samples were used for the statistical analysis. Cows were weighed at the start and at the end of the experiment.

\section{Chemical Analyses of Feedstuffs}

Fresh corn silage and grass hay samples were analyzed for DM content by oven drying at $105^{\circ} \mathrm{C}$ for 48 h. The chemical composition of corn silage was determined using lyophilized samples. All feed samples were ground in a mill [1-mm mesh; Retsch, Düsseldorf, Germany; adapted from AOAC method 950.02 (AOAC, 1995)] and stored at $4^{\circ} \mathrm{C}$ in hermetic boxes until analysis. They were then analyzed for DM content by oven

Table 2. Dry matter content and chemical composition of the main individual feedstuffs

\begin{tabular}{|c|c|c|c|c|c|c|c|c|}
\hline Item & $\begin{array}{l}\text { Corn } \\
\text { silage }\end{array}$ & $\begin{array}{l}\text { Grass } \\
\text { hay }\end{array}$ & $\begin{array}{l}\text { Sugar } \\
\text { beet } \\
\text { pulp }\end{array}$ & $\begin{array}{c}\text { Soybean } \\
\text { meal }\end{array}$ & $\begin{array}{c}\text { Alfalfa } \\
\text { protein } \\
\text { concentrate }\end{array}$ & $\begin{array}{l}\text { Extruded } \\
\text { linseed }\end{array}$ & $\begin{array}{l}\text { Extruded } \\
\text { rapeseed }\end{array}$ & $\begin{array}{l}\text { Mineral } \\
\text { and vitamin } \\
\text { mix }\end{array}$ \\
\hline DM, \% & 34.7 & 87.5 & 89.0 & 89.0 & 92.7 & 96.1 & 91.6 & 94.7 \\
\hline Crude ash & 4.2 & 6.8 & 5.7 & 7.2 & 8.5 & 4.7 & 3.9 & 61.6 \\
\hline $\mathrm{CP}$ & 8.4 & 8.6 & 8.3 & 51.0 & 58.2 & 20.9 & 17.9 & 6.0 \\
\hline NDF & 43.2 & 72.0 & 40.9 & 18.9 & 16.1 & 34.6 & 29.5 & 29.6 \\
\hline \multicolumn{9}{|l|}{ Fatty acid } \\
\hline Total fatty acids & 2.3 & 0.8 & 1.7 & 1.8 & 6.7 & 23.6 & 30.0 & 1.2 \\
\hline $6: 0-14: 0$ & 0.0 & 0.0 & 0.1 & 0.0 & 0.1 & 0.0 & 0.1 & 0.1 \\
\hline $16: 0$ & 0.4 & 0.2 & 0.3 & 0.3 & 1.2 & 1.4 & 1.6 & 0.3 \\
\hline 18:0 & 0.1 & 0.0 & 0.0 & 0.1 & 0.2 & 0.9 & 0.5 & 0.1 \\
\hline cis-9-18:1 & 0.5 & 0.1 & 0.2 & 0.3 & 0.3 & 5.0 & 16.4 & 0.4 \\
\hline $18: 2 \mathrm{n}-6$ & 0.9 & 0.1 & 0.6 & 1.0 & 1.1 & 4.0 & 6.5 & 0.2 \\
\hline
\end{tabular}


drying at $105^{\circ} \mathrm{C}$ for $16 \mathrm{~h}$ [adapted from AOAC methods 967.03 and 930.15 (AOAC, 1995)], crude ash by ashing at $550^{\circ} \mathrm{C}$ for $16 \mathrm{~h}$ [adapted from AOAC methods 923.03 , 967.04, and 942.05 (AOAC, 1995)], CP by the Kjeldahl method $[\mathrm{N} \times 6.25$; adapted from AOAC methods 981.10 and 991.20 (AOAC, 1995)], crude fat (adapted from directive 98/64/CE; Commission des Communautés européennes, 1998), NDF, and ADF (Van Soest et al., 1991). Neutral detergent fiber and ADF were determined sequentially and were expressed without residual ash. Neutral detergent fiber was analyzed with the addition of $\alpha$-amylase and without sodium sulfite. For the determination of FA profiles, lipids were extracted following the method of Folch modified by Christie (1982) and 13:0 (Sigma-Aldrich, St. Louis, MO) was used as an internal standard. Methylation and GLC analyses were performed as described below for milk samples.

\section{In Vitro Determination of Biohydrogenation Percentages of UFA in Rumen Fluid}

Ninety-five milligrams of EL, $75 \mathrm{mg}$ of ER, or 330 $\mathrm{mg}$ of APC was added into 100-mL flasks containing $400 \mathrm{mg}$ of grass hay as a source of feed particles. The amounts of EL, ER, and APC were calculated based on their total FA content (Table 2) to provide the same amount of FA for each dietary treatment. Ruminal fluid was obtained from 3 ruminally cannulated dry Holstein cows receiving grass hay ad libitum plus $1.5 \mathrm{~kg} / \mathrm{d}$ of a concentrate $(2 / 3$ barley $+1 / 3$ soybean meal) for 3 wk. Cows were housed in individual stalls, fed twice daily, and provided with water ad libitum. Ruminal fluid from each of the cows was collected before the a.m. meal, mixed together in equal proportions, strained through a metal sieve $(0.4 \mathrm{~mm}$ mesh), and finally brought to the laboratory under anaerobic conditions at $39^{\circ} \mathrm{C}$. The ruminal fluid mixture from the 3 cows was then mixed in a ratio 1:2 (vol:vol) with a buffer solution containing $(\mathrm{g} / \mathrm{L}) \mathrm{NaHCO}_{3}, 6.533 ; \mathrm{Na}_{2} \mathrm{HPO}_{4} \cdot 12 \mathrm{H}_{2} \mathrm{O}, 6.200 ; \mathrm{KCl}$, 0.380; $\mathrm{NaCl}, 0.313 ; \mathrm{CaCl}_{2}, 0.080 ; \mathrm{MgCl}_{2} \cdot 6 \mathrm{H}_{2} \mathrm{O}, 0.080$, pre-warmed at $39^{\circ} \mathrm{C}$ and saturated with $\mathrm{CO}_{2}(\mathrm{pH} 6.9)$. The mixture was then gassed with $\mathrm{CO}_{2}$ to maintain anaerobic conditions. Fifty milliliters of the mixture was transferred to each flask of the experimental set. Flasks were gassed with $\mathrm{CO}_{2}$ before closing, placed in a shaking water bath $\left(160 \mathrm{rpm}, 39^{\circ} \mathrm{C}\right)$ and incubated for 0,3 , 6,18 , or $24 \mathrm{~h}$. Flasks were incubated in triplicate for each treatment and each incubation time. Incubations were stopped by placing the flasks into iced water. Five milliliters of the homogenized content was collected and lyophilized. Fatty acids in the lyophilized samples were extracted and methylated in one step (Park and Goins, 1994) for FA analysis by GLC. Conditions for GLC analysis were as described below for milk samples.

\section{Milk Analyses}

Milk samples were refrigerated at $4^{\circ} \mathrm{C}$. A portion of each sample was used for fat, CP, and urea analyses by the mid-infrared spectroscopic method (adapted from AOAC method 972.16; AOAC, 1995) using the MilkoScan FT6000 spectrophotometer (Foss Analytical, Hillerød, Denmark) at the certified Milk Control Station [Battice, Belgium; Belgian accreditation number 262-TEST in compliance with International Organization for Standardization (ISO) 17025], and the rest of each sample was used for fat extraction.

Lipids from milk samples were extracted following the method described by Hara and Radin (1978). Milk samples were centrifuged at $17800 \times g$ at $4^{\circ} \mathrm{C}$ for 30 min, and 300 to $350 \mathrm{mg}$ of the fat cake was collected. Lipid extraction from milk fat was performed with 7.2 $\mathrm{mL}$ of a hexane/isopropanol (3:2, vol:vol) solution, followed by $4.8 \mathrm{~mL}$ of an $\mathrm{Na}_{2} \mathrm{SO}_{4}$ solution $(67 \mathrm{~g} / \mathrm{L})$. The upper phase was removed and dried with $1 \mathrm{~g}$ of anhydrous $\mathrm{Na}_{2} \mathrm{SO}_{4}$. It was then transferred again and brought to dryness under a continuous stream of $\mathrm{N}_{2}$. Fatty acids were first hydrolyzed in a solution of $\mathrm{KOH}$ in methanol $(0.1 \mathrm{M})$ at $70^{\circ} \mathrm{C}$ for $60 \mathrm{~min}$, then methylated in a solution of $\mathrm{HCl}$ in methanol $(1.2 \mathrm{M})$ at $70^{\circ} \mathrm{C}$ for $20 \mathrm{~min}$, and finally extracted with hexane.

Fatty acid methyl esters were separated and quantified with GLC (ThermoQuest Trace GC; Thermo Finnigan, Milan, Italy) equipped with a flame ionization detector, an automatic injector, and a fused silica capillary column $(100 \mathrm{~m} \times 0.25 \mathrm{~mm}$ i.d. $)$, coated with a $0.2-\mu \mathrm{m}$ film of biscyanopropyl polysiloxane (Rt-2560; Restek Corp., Bellefonte, PA). The system used $\mathrm{H}_{2}$ as the carrier gas operated at a constant pressure of $200 \mathrm{kPa}$. Injection was on column so as to inject the entire sample into the column head. This injection mode was preferred to the split-injection mode because it minimizes the risk of discrimination between milk FA with very different volatility. The initial oven temperature was $80^{\circ} \mathrm{C}$; it increased at $25^{\circ} \mathrm{C} / \mathrm{min}$ to $175^{\circ} \mathrm{C}$ (held for $25 \mathrm{~min}$ ), then increased at $10^{\circ} \mathrm{C} / \mathrm{min}$ to $205^{\circ} \mathrm{C}$ (held for $4 \mathrm{~min}$ ), then increased at $10^{\circ} \mathrm{C} / \mathrm{min}$ to $225^{\circ} \mathrm{C}$ (held for $20 \mathrm{~min}$ ), and finally decreased at $20^{\circ} \mathrm{C} / \mathrm{min}$ to $80^{\circ} \mathrm{C}$. The temperature of the flame ionization detector was maintained at $255^{\circ} \mathrm{C}$. Hydrogen flow to the detector was $35 \mathrm{~mL} /$ min and air flow was $350 \mathrm{~mL} / \mathrm{min}$. Each peak, except that of trans (t)10-18:1, was identified and quantified by comparison of retention times with pure fatty acid methyl ester (FAME) standards (Alltech Associates Inc., Deerfield, IL; except CLA isomers from Nu-Chek Prep Inc., Elysian, MN). Because no commercial standard was available for $t 10-18: 1$, the concentration of the corresponding peak was calculated by comparison with the t11-18:1 peak area (by multiplying the con- 
centration of $t 11-18: 1$ by the $t 10$ peak area-to- $t 11$ peak area ratio). The validity of this method was verified by applying it to the peak of $t 9-18: 1$ and comparing this calculated concentration with the t9-18:1 concentration determined through the use of the appropriate standard (Alltech Associates Inc.). Each FA was expressed as a percentage of all identified FA. The total identified FA accounted for $94.1 \pm 1.13 \%$ of the total measured FA (mean $\pm \mathrm{SD}$ ), as calculated by the ratio between the total area of identified peaks and the total area of identified and unidentified peaks. The analysis method did not allow quantification of 4:0, which is present in milk fat at $\pm 3 \%$ of the total theoretical FA (Jensen, 2002). Therefore, the total identified FA would account for $\pm 91 \%$ of the total theoretical FA. According to the literature, the $c 9, t 11$ CLA peak contained $c 9, t 11$ CLA and minor proportions of $t 7, c 9$ and $t 8, c 10$ CLA (CruzHernandez et al., 2006).

\section{Calculations}

The in vitro biohydrogenation percentage (\%) of a given FA at incubation time $\mathrm{t}$ was calculated as

$$
100-\frac{\text { Concentration of FA at time } \mathrm{t} \times 100}{\text { Concentration of FA at time } 0} .
$$

Individual milk FA yield (g/d) was calculated as

$$
\begin{aligned}
& \text { Individual milk FA yield }=\text { milk fat yield } \\
& \times \text { individual milk FA } \% / 100 \times 0.933 \times 0.91,
\end{aligned}
$$

where 0.933 is the mean proportion of FA in milk fat estimated by Glasser et al. (2007), 0.91 is the proportion of the identified FA in the total theoretical FA, and milk fat yield is expressed in $\mathrm{g} / \mathrm{d}$.

The apparent transfer efficiency of 18:2 n-6 and 18:3 n-3 from diet to milk could be estimated by dividing the milk 18:2 n-6 or 18:3 n-3 yield ( $\mathrm{g} / \mathrm{d}$ ) by its dietary intake $(\mathrm{g} / \mathrm{d})$.

\section{Statistical Analysis}

All data from the in vitro determination of biohydrogenation percentages of UFA in rumen fluid were analyzed using the ANOVA procedure of SAS (version 9.1.3; SAS Institute Inc., Cary, NC). Overall, differences between treatment means at each time of incubation were considered to be significant when $P<0.05$. When a significant treatment effect was observed, the Tukey option was used to compare means.

Data on milk composition and milk FA composition were averaged over d 19 and 21 of each period before statistical analyses. All data from the experiment are reported as least squares means \pm standard error of the means and were analyzed as a replicated Latin square using the MIXED procedure of SAS (version 9.1.3; SAS Institute Inc.). The statistical model included period, cow, diet, and random error. Fixed effects included period and diet. Cow was the random effect. Overall differences between treatment means were considered to be significant when $P<0.05$.

\section{RESULTS}

\section{In Vitro UFA Ruminal Biohydrogenation Percentages of Extruded Linseed, Extruded Rapeseed, and Alfalfa Protein Concentrate}

In vitro ruminal biohydrogenation percentages of 18:3 n-3, 18:2 n-6, and $c 9-18: 1$ at different incubation times are shown in Figure 1 for EL, ER, and APC. Biohydrogenation percentages of 18:3 n-3, 18:2 n-6, and c9-18:1 were similar for EL and ER at all time points, and higher than those of APC after $18 \mathrm{~h}$ of incubation $(P<0.05)$. At the end of the incubation $(24 \mathrm{~h})$, biohydrogenation percentages of 18:3 n-3 were 92, 91, and $67 \%$; those of $18: 2 \mathrm{n}-6$ were 86,94 , and $52 \%$; and those of $c 9-18: 1$ were 68,84 , and $33 \%$ for EL, ER, and APC, respectively.

\section{Nutrient Intake}

Nutrient intake of cows fed the 2 experimental diets is summarized in Table 3. Individual cow refusals throughout the experiment averaged $4 \pm 3.9 \%$ (mean $\pm \mathrm{SD}$ ) of offered DM. Because all individual cow refusals collected for each period were grass hay, refusals were only analyzed for DM content and the amount of grass hay refusals was subtracted from the amount of grass hay offered (DM basis). The amounts of diets were distributed as restricted TMR to control intakes. Accordingly, intakes of DM, OM, and NDF did not differ among diets $(P>0.05)$ and averaged 23.2, 21.8, and $9.7 \mathrm{~kg} / \mathrm{d}$, respectively. The intake of $\mathrm{CP}$ was higher for the EL diet compared with the ER-APC diet $(P$ $=0.03)$. On the contrary, the intake of crude fat was higher for the ER-APC diet compared with the EL $\operatorname{diet}(P=0.01)$. However, in agreement with the design of this experiment, the total FA intake did not differ among diets $(P>0.05)$ and averaged $925 \mathrm{~g} / \mathrm{d}$. The discrepancy between crude fat and total FA intakes for the 2 diets was due to the low proportion of total FA in crude fat for APC (0.38) compared with EL and ER (0.90 and 0.86; Table 2). Differences appeared between the 2 diets in terms of intakes of some FA, mainly $c 9$ 18:1 and 18:3 n-3. As a result, 18:3 n-3 was the main 
(a) $18: 3 n-3$

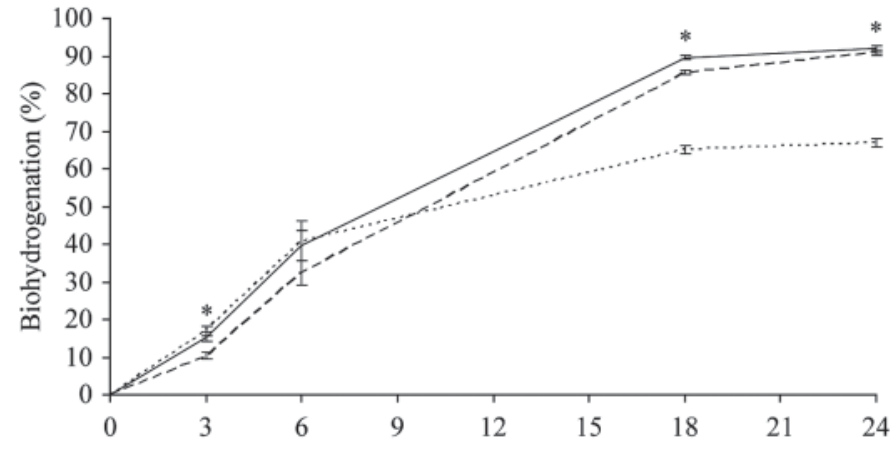

(b) $18: 2 \mathrm{n}-6$

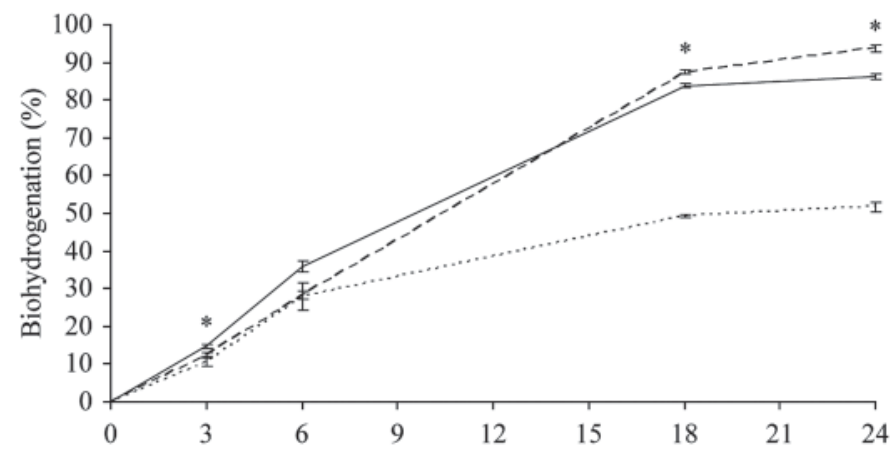

(c) c9-18:1

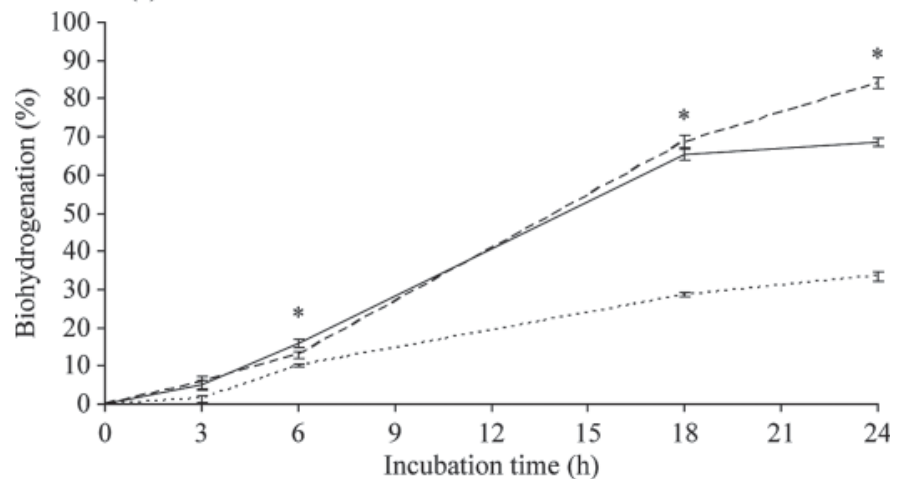

Figure 1. In vitro ruminal biohydrogenation percentages of $18: 3$ n-3 (a), 18:2 n-6 (b), and cis-9-18:1 (c) for extruded linseed (solid line), extruded rapeseed (dashed line), and alfalfa protein concentrate (dotted line). Error bars indicate standard error of the means $(\mathrm{n}=3)$. Means marked with $*$ differ significantly $(P<0.05)$.

FA consumed in the EL diet, followed by 18:2 n- 6 and $c 9-18: 1$ (35, 27, and $20 \%$ of total FA intake, respectively), whereas $c 9-18: 1$ was the main FA consumed in the ER-APC diet, followed by 18:2 n- 6 and 18:3 n-3 $(33,28$, and $19 \%$ of total FA intake, respectively). Cows did not lose weight during the experiment $(636 \pm 25.3$ vs. $642 \pm 31.2 \mathrm{~kg}$ of BW, respectively at the onset and at the end of the experiment), suggesting that energy requirements were met.

\section{Milk Yield and Composition}

Milk yield and composition of cows fed the 2 experimental diets are shown in Table 4. Milk, 4\% FCM, and fat yields were not affected by diets $(P>0.05)$ and averaged $28.7,29.3$, and $1.19 \mathrm{~kg} / \mathrm{d}$, respectively. The efficiency of milk production, in terms of $4 \% \mathrm{FCM}$ yield $(\mathrm{kg})$ per kilogram of DMI, did not differ among diets $(P$ $>0.05)$ and averaged 1.27. Fat and protein percentages were not affected by diets $(P>0.05)$ and averaged 4.21 and $3.21 \%$, respectively. On the contrary, the protein yield was higher for the EL diet compared with the ER-APC diet $(P=0.02)$. However, this difference could be considered as having no or negligible biological significance in spite of having statistical significance. The milk urea concentration was lower for the ER-APC diet compared with the EL diet $(P=0.01)$.

\section{Milk FA Composition and Yield}

The milk FA composition of cows fed the 2 experimental diets is shown in Table 5. Milk concentrations of 16:0, 18:0, $t 10-18: 1$, PUFA, UFA, SFA, and C20-C22 did not differ between the EL and ER-APC diets $(P$ $>0.05)$. Milk concentrations of $6: 0$ to $14: 0$; t11-18:1; $c 9, t 11$ CLA, and total trans C18 FA were higher for the EL diet compared with the ER-APC diet. On the contrary, milk concentrations of $c 9-18: 1,18: 2$ n-6, 18:3 n-3, total C18 FA, and monounsaturated fatty acids (MUFA) were higher for the ER-APC diet compared with the EL diet.

The milk FA yields of cows fed the 2 experimental diets are shown in Table 6. Milk FA yields did not differ among diets $(P>0.05)$, except for $c 9, t 11$ CLA and total trans $\mathrm{C} 18 \mathrm{FA}$, whose yields were higher for the EL diet. The transfer efficiency of 18:3 n-3 in milk was almost twice as much for the ER-APC diet as for the EL diet. The transfer efficiency of 18:2 n-6 in milk did not differ among diets $(P>0.05)$.

\section{DISCUSSION}

Compared with the FA composition of a winter Dutch milk (mean from 1,822 milk samples from individual cows between February and March 2005; Rutten et al., 2009) and a year-round Dutch milk (mean from 52 bulk milk samples from 17 dairy plants collected every week between February 2005 and February 2006; Heck et al., 2009), milks from the EL diet (EL milk) and the ER-APC diet (ER-APC milk) exhibited higher concentrations of $18: 3 \mathrm{n}-3$ (1.18 and 1.31 vs. 0.42 and $0.50 \%$ of $\mathrm{FA}$, respectively, for EL, ER-APC, winter, and year-round milks); $c 9, t 11$ CLA (1.24 and 1.00 vs. 0.39 and $0.54 \%$ of FA, respectively); and lower ratios 
Table 3. Nutrient intake of cows fed the 2 experimental diets

\begin{tabular}{|c|c|c|c|c|}
\hline \multirow[b]{2}{*}{ Intake } & \multicolumn{2}{|c|}{$\operatorname{Diet}^{1}$} & \multirow[b]{2}{*}{ SEM } & \multirow[b]{2}{*}{$P$-value } \\
\hline & EL & ER-APC & & \\
\hline \multicolumn{5}{|l|}{ Nutrient intake, $\mathrm{kg} / \mathrm{d}$} \\
\hline DM & 23.6 & 22.7 & 0.37 & NS \\
\hline $\mathrm{OM}$ & 22.2 & 21.3 & 0.35 & NS \\
\hline Crude ash & 1.4 & 1.4 & 0.02 & NS \\
\hline $\mathrm{CP}$ & 3.7 & 3.5 & 0.06 & 0.03 \\
\hline $\mathrm{NDF}$ & 9.8 & 9.5 & 0.15 & NS \\
\hline $\mathrm{ADF}$ & 5.5 & 5.1 & 0.08 & 0.02 \\
\hline Crude fat & 1.8 & 2.0 & 0.03 & 0.01 \\
\hline \multicolumn{5}{|l|}{ Fatty acid intake, $\mathrm{g} / \mathrm{d}$} \\
\hline Total fatty acids & 918 & 931 & 15.6 & NS \\
\hline Total C18 fatty acids & 785 & 761 & 12.9 & NS \\
\hline $6: 0-14: 0$ & 10 & 11 & 0.2 & $<0.01$ \\
\hline $16: 0$ & 102 & 112 & 1.8 & 0.01 \\
\hline 18:0 & 30 & 20 & 0.4 & $<0.01$ \\
\hline cis-9-18:1 & 185 & 311 & 4.9 & $<0.01$ \\
\hline $18: 2 \mathrm{n}-6$ & 252 & 258 & 4.2 & NS \\
\hline $18: 3$ n-3 & 318 & 172 & 3.7 & $<0.01$ \\
\hline
\end{tabular}

${ }^{1} \mathrm{EL}=$ extruded linseed diet; ER-APC $=$ extruded rapeseed-alfalfa protein concentrate diet.

of 18:2 n-6/18:3 n-3 (1.69 and 1.64 vs. 2.83 and 2.56, respectively). Moreover, when compared with the same winter (Rutten et al., 2009) and year-round (Heck et al., 2009) milks, the EL and ER-APC milks exhibited higher concentrations of $t 11-18: 1$ (2.99 and 2.37 vs. 0.78 and $1.12 \%$ of FA, respectively), whose presence in milk fat may have a positive effect on some aspects of human health because human tissues can partially convert $t 11$ 18:1 to $c 9, t 11$ CLA via $\Delta^{9}$-desaturase (Renaville et al., 2006). To a lesser extent, when compared with winter milk (Rutten et al., 2009), the EL and ER-APC milks exhibited lower concentrations of 16:0 (29.35 and 28.77 vs. $32.61 \%$ of FA, respectively, for EL, ER-APC, and winter milks) and 12:0 (3.57 and 3.70 vs. $4.10 \%$ of FA, respectively), and lower ratios of SFA/UFA (2.32 and 2.21 vs. 2.81 , respectively). Besides, the ER-APC milk exhibited a higher concentration of $c 9-18: 1$ compared with the winter (Rutten et al., 2009) and year-round (Heck et al., 2009) milks (20.01 vs. 18.03 and $17.60 \%$ of FA, respectively, for ER-APC, winter and year-round milks). Differences in terms of milk FA concentrations between winter and year-round milks, on the one hand, and EL and ER-APC milks, on the other hand, can be partly attributed to differences in FA intakes. The major ingredients in Dutch dairy cow rations include fresh grass, grass silage, corn silage, and concentrates, and the lipids present in these feedstuffs usually account for only 2 to $4 \%$ of the diet (DM basis), whereas in EL and ER-APC diets, the lipid inclusion, and subsequent FA intake, was much higher (7.6 to 8.8 and 3.9 to $4.1 \%$ of DM, respectively; calculated from Table 3 ), due to the supplementation with EL, ER, and APC. Regarding UFA, $c 9-18: 1$ and SMCFA, these observations are in line with those of Gonthier et al. (2005) and Akraim et al. (2007) for linseed supplementation, and Bayourthe et al. (2000) and Collomb et al. (2004) for rapeseed supplementation. However, rapeseed only had little (Bayourthe et al., 2000) or no effect (Collomb et al., 2004) on the concentration of 18:3 n-3 in milk fat. The level of lipid inclusion in the diet might, however, not

Table 4. Milk yield and composition of cows fed the 2 experimental diets

\begin{tabular}{lccccc}
\hline & \multicolumn{2}{c}{ Diet $^{1}$} & & \\
\cline { 2 - 3 } Item & EL & ER-APC & SEM & P-value \\
\hline Milk, $\mathrm{kg} / \mathrm{d}$ & 29.4 & 28.0 & 1.47 & $\mathrm{NS}$ \\
$4 \% \mathrm{FCM}, \mathrm{kg} / \mathrm{d}$ & 30.0 & 28.6 & 0.99 & $\mathrm{NS}$ \\
Fat, $\mathrm{kg} / \mathrm{d}$ & 1.22 & 1.16 & 0.043 & $\mathrm{NS}$ \\
Protein, $\mathrm{kg} / \mathrm{d}$ & 0.94 & 0.88 & 0.037 & 0.02 \\
Fat, $\%$ & 4.24 & 4.18 & 0.242 & $\mathrm{NS}$ \\
Protein, $\%$ & 3.22 & 3.20 & 0.058 & $\mathrm{NS}$ \\
Urea, $\mathrm{mg} / \mathrm{L}$ & 233 & 166 & 11.3 & 0.01 \\
Efficiency of milk production, $\mathrm{kg}$ of $4 \% \mathrm{FCM} / \mathrm{kg}$ of DMI & 1.27 & 1.26 & 0.039 & $\mathrm{NS}$ \\
\hline
\end{tabular}

${ }^{1} \mathrm{EL}$ diet $=$ extruded linseed diet; ER-APC diet = extruded rapeseed-alfalfa protein concentrate diet. 
Table 5. Milk fatty acid composition (\% identified fatty acids) of cows fed the 2 experimental diets

\begin{tabular}{|c|c|c|c|c|}
\hline \multirow[b]{2}{*}{ Fatty acid ${ }^{1}$} & \multicolumn{2}{|c|}{$\operatorname{Diet}^{2}$} & \multirow[b]{2}{*}{ SEM } & \multirow[b]{2}{*}{$P$-value } \\
\hline & EL & ER-APC & & \\
\hline $6: 0$ & 2.70 & 2.59 & 0.093 & NS \\
\hline $8: 0$ & 1.63 & 1.54 & 0.066 & 0.01 \\
\hline $10: 0$ & 3.38 & 3.16 & 0.149 & 0.01 \\
\hline $12: 0$ & 3.57 & 3.70 & 0.144 & 0.02 \\
\hline $13: 0$ & 0.17 & 0.17 & 0.016 & NS \\
\hline $14: 0$ & 12.35 & 11.98 & 0.411 & 0.03 \\
\hline Iso-14:0 & 0.09 & 0.08 & 0.007 & NS \\
\hline$c 9-14: 1$ & 1.02 & 1.00 & 0.085 & NS \\
\hline 15:0 & 0.99 & 1.09 & 0.029 & NS \\
\hline Iso- $15: 0$ & 0.25 & 0.20 & 0.005 & 0.01 \\
\hline Anteiso-15:0 & 0.58 & 0.57 & 0.030 & NS \\
\hline $16: 0$ & 29.35 & 28.77 & 1.644 & NS \\
\hline Iso-16:0 & 0.29 & 0.34 & 0.027 & NS \\
\hline$c 9-16: 1$ & 1.30 & 1.34 & 0.205 & NS \\
\hline$t 9-16: 1$ & 0.16 & 0.14 & 0.021 & NS \\
\hline $17: 0$ & 0.57 & 0.61 & 0.015 & 0.03 \\
\hline Iso-17:0 & 0.34 & 0.27 & 0.021 & 0.01 \\
\hline Anteiso-17:0 & 0.59 & 0.55 & 0.040 & 0.04 \\
\hline $18: 0$ & 12.46 & 12.96 & 0.767 & NS \\
\hline$c 9-18: 1$ & 18.35 & 20.01 & 0.542 & 0.01 \\
\hline$c 11-18: 1$ & 0.47 & 0.73 & 0.037 & 0.01 \\
\hline$t 9-18: 1$ & 0.40 & 0.54 & 0.038 & 0.01 \\
\hline$t 10-18: 1$ & 0.54 & 0.72 & 0.071 & NS \\
\hline$t 11-18: 1$ & 2.99 & 2.37 & 0.408 & 0.03 \\
\hline $18: 2 \mathrm{n}-6$ & 1.96 & 2.11 & 0.193 & 0.03 \\
\hline$c 9, t 11 \mathrm{CLA}^{3}$ & 1.24 & 1.00 & 0.160 & 0.01 \\
\hline$t 9, t 12-18: 2$ & 0.33 & 0.12 & 0.037 & 0.01 \\
\hline $18: 3 n-3$ & 1.18 & 1.31 & 0.154 & 0.04 \\
\hline $20: 0$ & 0.12 & 0.20 & 0.012 & 0.01 \\
\hline$c 11, c 14, c 17-20: 3$ & $\mathrm{ND}^{4}$ & ND & $\mathrm{NA}^{5}$ & NA \\
\hline$c 5, c 8, c 11, c 14-20: 4$ & 0.07 & 0.06 & 0.014 & NS \\
\hline$c 5, c 8, c 11, c 14, c 17-20: 5$ & 0.45 & 0.05 & 0.304 & NS \\
\hline$c 7, c 10, c 13, c 16, c 19-22: 5$ & 0.08 & 0.08 & 0.021 & NS \\
\hline$c 4, c 7, c 10, c 13, c 16, c 19-22: 6$ & ND & ND & $\mathrm{NA}$ & NA \\
\hline $6: 0-14: 0$ & 23.79 & 22.81 & 0.787 & 0.01 \\
\hline Total trans $\mathrm{C} 18$ fatty acids & 5.53 & 4.75 & 0.643 & 0.03 \\
\hline Total C18 fatty acids & 39.95 & 41.87 & 1.552 & 0.01 \\
\hline $\mathrm{C} 20-\mathrm{C} 22$ & 0.60 & 0.18 & 0.301 & NS \\
\hline Monounsaturated fatty acids & 25.24 & 26.84 & 1.006 & 0.01 \\
\hline Polyunsaturated fatty acids & 5.33 & 4.72 & 0.722 & NS \\
\hline Saturated fatty acids & 69.44 & 68.44 & 1.644 & NS \\
\hline Unsaturated fatty acids & 30.56 & 31.56 & 1.644 & NS \\
\hline $18: 2 n-6 / 18: 3 n-3$ & 1.69 & 1.64 & 0.051 & NS \\
\hline Saturated fatty acids/unsaturated fatty acids & 2.32 & 2.21 & 0.168 & NS \\
\hline
\end{tabular}

totally explain the differences in milk UFA observed between regular Dutch milks and the ones obtained in the present experiment. A partial protection from thorough biohydrogenation also appears to play a role. The in vitro biohydrogenation percentages presented in Figure 1 indicate that the UFA from APC were less completely biohydrogenated than those from EL and ER. In line with these in vitro data, the results obtained with the ER-APC diet, where rapeseed was associated with APC, showed a higher milk concentration of 18:3 $\mathrm{n}-3$, in addition to the increase in UFA and $c 9-18: 1$ and decrease in SMCFA induced by rapeseed. Overall, our results show that EL and ER + APC, incorporated as UFA sources into corn silage-based diets, are 2 effective means of improving the milk FA profile.

In this experiment, milk concentrations of $c 9, t 11$ CLA and t11-18:1, the main biohydrogenation intermediates, were higher for the EL diet compared with 
Table 6. Milk fatty acid yields of cows fed the 2 experimental diets

\begin{tabular}{|c|c|c|c|c|}
\hline \multirow[b]{2}{*}{ Item $^{1}$} & \multicolumn{2}{|c|}{$\operatorname{Diet}^{2}$} & \multirow[b]{2}{*}{ SEM } & \multirow[b]{2}{*}{$P$-value } \\
\hline & EL & ER-APC & & \\
\hline \multicolumn{5}{|l|}{ Fatty acid yield, g/d } \\
\hline $6: 0-16: 0$ & 551 & 508 & 30.3 & NS \\
\hline $18: 0$ & 128 & 128 & 9.0 & NS \\
\hline$c 9-18: 1$ & 190 & 196 & 6.9 & NS \\
\hline$t 11-18: 1$ & 31 & 23 & 3.5 & NS \\
\hline $18: 2 \mathrm{n}-6$ & 20 & 21 & 1.7 & NS \\
\hline$c 9, t 11 \mathrm{CLA}^{3}$ & 13 & 10 & 1.5 & 0.01 \\
\hline $18: 3 \mathrm{n}-3$ & 12 & 13 & 1.3 & NS \\
\hline Total trans $\mathrm{C} 18$ fatty acids & 57 & 46 & 5.6 & 0.04 \\
\hline Total C18 fatty acids & 412 & 411 & 15.6 & NS \\
\hline Saturated fatty acids & 719 & 675 & 35.3 & NS \\
\hline Unsaturated fatty acids & 315 & 309 & 14.7 & NS \\
\hline Total fatty acids & 1,034 & 983 & 36.9 & NS \\
\hline \multicolumn{5}{|c|}{ Transfer efficiency from diet to milk, $\%$ intake } \\
\hline $18: 2 n-6$ & 8.0 & 8.0 & 0.63 & NS \\
\hline $18: 3 \mathrm{n}-3$ & 3.8 & 7.4 & 0.62 & $<0.01$ \\
\hline
\end{tabular}

the ER-APC diet. This might partly be because of the higher protection of UFA provided by APC in the ERAPC diet. Quantitatively speaking, the main reason for that difference is most likely the higher intake of PUFA with the EL diet (despite similar total FA intake). Accordingly, Rego et al. (2009) showed that higher milk concentrations of biohydrogenation intermediates were obtained with linseed oil (source of 18:3 n-3) compared with rapeseed oil (source of $c 9-18: 1$ ), and the lack of effect on t11-18:1, and subsequently on $c 9, t 11$ CLA in milk fat, of rapeseed supplementation suggested that $t 11-18: 1$ is not the main product of rumen microbial isomerization of $c 9-18: 1$.

In the present study, extruded material was used either from linseed or from rapeseed. The extrusion process has been claimed to offer a certain level of protection to the UFA. It has been proposed that this process would denature the protein matrix that might have encapsulated or tied up FA, and in turn, make them less available for ruminal biohydrogenation (Kennelly, 1996; Petit et al., 1997). Moreover, the temperature of preconditioning and the increase in temperature between the preconditioning and extrusion steps have also been reported to strongly influence oil availability and subsequent milk FA profile (Chesneau et al., 2009). As an example, Akraim et al. (2007) showed that extruded, compared with raw, ground linseed leads to increased milk proportions of 18:3 n-3 and ruminal biohydrogenation intermediates, including $c 9, t 11$ CLA. However, reported effects of extrusion processes on ruminal degradability of oilseeds are inconsistent and hardly complete. Indeed, some authors showed that extruded oilseeds decreased UFA ruminal biohydrogenation compared with raw oilseeds (Chapoutot and Sauvant, 1997; Chouinard et al., 1997; Akraim et al., 2007), whereas others did not come to the same conclusions (Gonthier et al., 2005; Akraim et al., 2006; Doreau et al., 2009).

The transfer efficiency of 18:3 n-3 into milk was almost twice as much for the ER-APC diet as for the EL diet. Based on the proportion of EL in the EL diet (Table 1), the proportion of 18:3 n-3 in EL (Table 2) and the calculated proportion of 18:3 n-3 in the EL diet as consumed (Table 3), we estimated that EL accounted for approximately $84 \%$ of the $18: 3 \mathrm{n}-3$ provided in the EL diet. With the same approach, ER and APC accounted for approximately 33 and $38 \%$ of $18: 3$ n-3 provided in the ER-APC diet, respectively. Both EL and ER underwent extrusion in similar conditions, resulting in their in vitro UFA ruminal biohydrogenation percentages being similar. In vitro data also indicated that the UFA from APC, and thus 18:3 n-3, were partially protected from biohydrogenation. Taken together, our results, therefore, suggest that 18:3 n-3 of EL in the EL diet and ER in the ER-APC diet were subjected to more extensive ruminal biohydrogenation than 18:3 n-3 of APC in the ER-APC diet. Another explanation might be the difference in 18:3 n-3 levels in the 2 experimental diets. Akraim et al. (2007) suggested that the extent of ruminal biohydrogenation of 18:3 n-3 is increased when its dietary supply was high, which was the case for the EL diet. The transfer efficiency of 18:2 n-6 into milk did not differ among diets. This was expected because the main source of 18:2 n- 6 for the 2 diets was corn 
silage, which accounted for approximately 42 and $40 \%$ provided in the EL and ER-APC diets, respectively. Extruded linseed accounted for approximately $34 \%$ of 18:2 n- 6 provided in the EL diet, whereas ER and APC accounted for approximately 39 and $9 \%$ of $18: 2$ n-6 provided in the ER-APC diet, respectively. Because APC was a minor source of 18:2 n-6, a potential influence of partially protected 18:2 n-6 from APC on its milk level would not have been noticed. In contrast, the major sources of 18:2 n-6, which were EL in the EL diet and ER in the ER-APC diet, were most likely equally subjected to ruminal biohydrogenation. The transfer efficiency of $c 9-18: 1$ in milk could not be assessed because mammary $\Delta^{9}$-desaturation of $18: 0$ is responsible for $80 \%$ of the yield of $c 9-18: 1$ in milk (Glasser et al., 2008).

Heat coagulation and dehydration during the alfalfa plant fractionation process increase ruminal bypass of alfalfa proteins (Lu et al., 1982; Nishino et al., 1994) and may, subsequently, protect alfalfa lipids from ruminal biohydrogenation by a mechanism similar to that of extruded oilseeds. Furthermore, differences of 18:3 n-3 transfer efficiencies from diet to milk observed for EL and ER-APC diets, together with in vitro biohydrogenation percentages of 18:3 n-3, 18:2 n-6, and $c 9-18: 1$ for EL, ER, and APC, suggest that the level of protection of UFA from ruminal biohydrogenation provided by the heat treatment (temperature and duration) as well as the source of protein of EL and ER was lower than that of APC.

In this experiment, soybean meal, as the main protein source in the EL diet was totally replaced by APC in the ER-APC diet. The digestible proteins from dietary origin entering the small intestine (PDIA; directly originating from proteins that are not degraded in the rumen; INRA, 2007) values were higher for APC than for soybean meal ( 433 vs. $201 \mathrm{~g} / \mathrm{kg}$ of DM; estimated from INRA, 2007). Accordingly, milk urea concentration was lower for the ER-APC diet compared with the EL diet. This observation seems to confirm the better resistance to ruminal degradation of APC proteins compared with those of soybean meal, as already shown by Lu et al. (1982, 1988). Besides, the higher CP intake with the EL diet may also have contributed to the higher milk urea concentration with this diet compared with the ER-APC diet.

\section{CONCLUSIONS}

This experiment shows that corn silage-based diets supplemented with ER as the main UFA source and APC as supplemental 18:3 n-3 source are as effective as corn silage-based diets supplemented with EL as the main UFA and 18:3 n-3 source in increasing bovine milk
UFA and 18:3 n-3 contents. Furthermore, at similar levels of dietary incorporation, ruminal bypass of UFA is higher for APC compared with EL. Subsequently, the transfer efficiency of 18:3 n-3 from diet to milk is higher for APC compared with EL. However, further investigations with multiple levels of 18:3 n-3 intake are necessary to confirm this observation.

\section{ACKNOWLEDGMENTS}

The authors are deeply indebted to G. Collignon, M. Lucas, and L. Van De Steene from the Université catholique de Louvain (Louvain-la-Neuve, Belgium) and T. Relekom from the Centre wallon de Recherches agronomiques (Gembloux, Belgium) for animal care, feeding, sampling, and laboratory analyses.

\section{REFERENCES}

Akraim, F., M. C. Nicot, P. Juaneda, and F. Enjalbert. 2007. Conjugated linolenic acid (CLnA), conjugated linoleic acid (CLA) and other biohydrogenation intermediates in plasma and milk fat of cows fed raw or extruded linseed. Animal 1:835-843.

Akraim, F., M.-C. Nicot, P. Weill, and F. Enjalbert. 2006. Effects of preconditioning and extrusion of linseed on the ruminal biohydrogenation of fatty acids. 1. In vivo studies. Anim. Res. 55:83-91.

AOAC. 1995. Official Methods of Analysis. 16th ed. Association of Official Analytical Chemists, Arlington, VA.

Bayourthe, C., F. Enjalbert, and R. Moncoulon. 2000. Effects of different forms of canola oil fatty acids plus canola meal on milk composition and physical properties of butter. J. Dairy Sci. 83:690-696.

Chapoutot, P., and D. Sauvant. 1997. Nutritive value of raw and extruded pea-rapeseed blends for ruminants. Anim. Feed Sci. Technol. 65:59-77.

Chesneau, G., S. Burban, F. Millet, and P. Weill. 2009. Qualité du traitement des graines oléagineuses par cuisson-extrusion: Matière grasse disponible. Page 62 in 16èmes Rencontres autour des Recherches sur les Ruminants, Paris, France. Institut de l'ÉlevageINRA, Paris, France.

Chouinard, P. Y., J. Lévesque, V. Girard, and G. J. Brisson. 1997. Dietary soybeans extruded at different temperatures: Milk composition and in situ fatty acid reactions. J. Dairy Sci. 80:2913-2924.

Christie, W. W. 1982. Lipid Analysis. 2nd ed. Pergamon Press, Oxford, UK.

Collomb, M., H. Sollberger, U. Bütikofer, R. Sieber, W. Stoll, and W. Schaeren. 2004. Impact of a basal diet of hay and fodder beet supplemented with rapeseed, linseed and sunflowerseed on the fatty acid composition of milk fat. Int. Dairy J. 14:549-559.

Commission des Communautés européennes. 1998. Directive 98/64/ $\mathrm{CE}$ de la Commission du 3 septembre 1998 portant fixation des méthodes d'analyses communautaires pour la détermination des acides aminés, des matières grasses brutes et de l'olaquinox dans les aliments des animaux et modifiant la directive $71 / 393 / \mathrm{CEE}$ (Texte présentant de l'intérêt pour l'EEE). Pages 14-28 in Journal officiel des Communautés européennes du 19.9.98 L257.

Cruz-Hernandez, C., J. K. G. Kramer, J. Kraft, V. Santercole, M. Or-Rashid, Z. Deng, M. E. R. Dugan, P. Delmonte, and M. P. Yurawecz. 2006. Systematic analysis of trans and conjugated linoleic acids in the milk and meat of ruminants. Pages 45-93 in Advances in Conjugated Linoleic Acid Research. Vol. 3. M. P. Yurawecz, J. K. G. Kramer, O. Gudmundsen, M. W. Pariza, and S. Banni, ed. AOCS Press, Champaign, IL.

Doreau, M., S. Laverroux, J. Normand, G. Chesneau, and F. Glasser. 2009. Effect of linseed fed as rolled seeds, extruded seeds or oil on fatty acid rumen metabolism and intestinal digestibility in cows. Lipids $44: 53-62$. 
Focant, M., E. Mignolet, M. Marique, F. Clabots, T. Breyne, D. Dalemans, and Y. Larondelle. 1998. The effect of vitamin E supplementation of cow diets containing rapeseed and linseed on the prevention of milk fat oxidation. J. Dairy Sci. 81:1095-1101.

Glasser, F., M. Doreau, A. Ferlay, and Y. Chilliard. 2007. Technical note: Estimation of milk fatty acid yield from milk fat data. J. Dairy Sci. 90:2302-2304.

Glasser, F., A. Ferlay, M. Doreau, P. Schmidely, D. Sauvant, and Y. Chilliard. 2008. Long-chain fatty acid metabolism in dairy cows: A meta-analysis of milk fatty acid yield in relation to duodenal flows. J. Dairy Sci. 91:2771-2785.

Gonthier, C., A. F. Mustafa, D. R. Ouellet, P. Y. Chouinard, R. Berthiaume, and H. V. Petit. 2005. Feeding micronized and extruded flaxseed to dairy cows: Effects on blood parameters and milk fatty acid composition. J. Dairy Sci. 88:748-756.

Hara, A., and N. S. Radin. 1978. Lipid extraction of tissues with a low-toxicity solvent. Anal. Biochem. 90:420-426.

Heck, J. M. L., H. J. F. van Valenberg, J. Dijkstra, and A. C. M. van Hooijdonk. 2009. Seasonal variation in the Dutch bovine raw milk composition. J. Dairy Sci. 92:4745-4755.

INRA. 2007. Alimentation des bovins, ovins et caprins. Besoins des animaux - Valeurs des aliments. Institut National de la Recherche Agronomique, Paris, France.

Jensen, R. G. 2002. Invited review: The composition of bovine milk lipids: January 1995 to December 2000. J. Dairy Sci. 85:295-350.

Kennelly, J. J. 1996. The fatty acid composition of milk fat as influenced by feeding oilseeds. Anim. Feed Sci. Technol. 60:137-152.

Kim, E. J., R. I. Richardson, K. Gibson, D. Coulmier, and N. D. Scollan. 2009. Effect of diet and breed on fatty acid composition of beef steers. Pages 438-439 in Proceedings of the XIth International Symposium on Ruminant Physiology, Clermont-Ferrand, France.

Lu, C. D., N. A. Jorgensen, and C. H. Amundson. 1982. Ruminal degradation and intestinal absorption of alfalfa protein concentrate by sheep. J. Anim. Sci. 54:1251-1262.
Lu, C. D., N. A. Jorgensen, and L. D. Satter. 1988. Site and extent of nutrient digestion in lactating dairy cows fed alfalfa protein concentrate or soybean meal. J. Dairy Sci. 71:697-704.

Nishino, N., S. Uchida, and M. Ohshima. 1994. Ruminal degradation of alfalfa protein as influenced by sodium hydroxide and heat treatment. Anim. Feed Sci. Technol. 48:131-141.

Park, P. W., and R. E. Goins. 1994. In situ preparation of fatty acid methyl esters for analysis of fatty acid composition in foods. J. Food Sci. 59:1262-1266.

Petit, H. V., R. Rioux, P. S. D'Oliveira, and I. N. do Prado. 1997. Performance of growing lambs fed grass silage with raw or extruded soybean or canola seeds. Can. J. Anim. Sci. 77:455-463.

Rego, O. A., S. P. Alves, L. M. Antunes, H. J. Rosa, C. F. Alfaia, J. A Prates, A. R. Cabrita, A. J. Fonseca, and R. J. Bessa. 2009. Rumen biohydrogenation-derived fatty acids from grazing dairy cows supplemented with rapeseed, sunflower, or linseed oils. J. Dairy Sci. 92:4530-4540.

Renaville, B., A. Mullen, F. Moloney, Y. Larondelle, Y. J. Schneider, and H. M. Roche. 2006. Eicosapentaenoic acid and 3,10 dithia stearic acid inhibit the desaturation of trans-vaccenic acid into cis9, trans-11-conjugated linoleic acid through different pathways in Caco-2 and T84 cells. Br. J. Nutr. 95:688-695.

Rutten, M. J. M., H. Bovenhuis, K. A. Hettinga, H. J. F. van Valenberg, and J. A. M. van Arendonk. 2009. Predicting bovine milk fat composition using infrared spectroscopy based on milk samples collected in winter and summer. J. Dairy Sci. 92:6202-6209.

Van Soest, P. J., J. B. Robertson, and B. A. Lewis. 1991. Methods for dietary fiber, neutral detergent fiber and non starch polysaccharides in relation to animal nutrition. J. Dairy Sci. 74:3583-3597. 